\title{
Impact of Chemicals on the Ripening Physiology of Fruits
}

\author{
Pawandeep Singh, Ankush Tarkha, Prassan Kumar and Jatinder Singh* \\ School of Agriculture, Lovely Professional University, Phagwara, Punjab, India \\ *Corresponding author
}

\section{A B S T R A C T}

\section{Keywords \\ Agriculture, Climate, Guava, Ripening}

\section{Article Info}

Accepted: 04 November 2020 Available Online: 10 December 2020
The invention of new chemicals or molecules, which may lead to or delay the ripening process of fruits, so that losses due to their perishable nature and short storage life can be easily handled. By doing this manipulation, we can avoid huge economic losses during the peak fruit season. It is prudent to use chemicals within safe limits so that they do not have a negative effect on a healthy human being. Certain chemicals increase the ripening process only if they are used in higher quantities but lead to a decline in the shelf life of treated fruits. In addition, the fruits have decayed very early compared to untreated fruits. In this article, we are focusing on the possibilities of manipulation in the process of maturation by the use of different chemicals.

\section{Introduction}

Guava is a very important fruit crop, grown in several parts of the world because of its wider adaptability. This fruit is also known as the "apple of the tropics" and is popularly known as the "poor man's apple" because of its availability and lower cost. Due to its nutritional value, refreshing taste and pleasant taste, this fruit is of great benefit to consumers. This fruit belongs to the Myrtaceae family and is native to Tropical America. The highest production of guava in India is in Uttar Pradesh, accounting for 22.93 per cent of total production. Punjab ranks 7 th in the production of guava with a total area of 8690 ha and a total production of $195600 \mathrm{MT}$ and a share of 4.83 percent of India's total production (Anon, 2018). Guava flowering occurs twice in northern India. It is a good source of iron, including pectin and vitamins such as 'A,' 'C,' E, thiamine, niacin and riboflavin, along with minerals such as $\mathrm{Ca}$ (14-30 mg/100 gm) and P (23.37 mg/100 gm) etc. Guava fruits are used for direct consumption or for processing purposes in the manufacture of various products (Boora, 2012). Up to harvesting, the life of fruit can be categorized into three stages:

Fruit set

Development of fruit

Ripening of fruit 
Fruit ripening is a genetically programmed process. Fruit ripening is a very complicated process resulting from a change in the taste, colour, texture and other characteristics of the fruit. When ripening is at an early stage due to the production of a high amount of ethylene, respiration is at its peak, while this rate is almost persistent and shows little decline towards senescence, indicating a decrease in ethylene production (Bouzayen et al., 2010). Dal RI et al., (2010) concluded that ethylene plays an important role in the development and growth of grapevine berry. Korban et al., (2010) also stated that the change in fruit texture is affected by genetic regulatory factors such as environmental conditions. At the time of the respiration process, complex molecules are broken into simpler ones, resulting in energy supply. Tripathi et al., (2016) indicated from cellular metabolic activity that the process of fruit maturation is a distinguishing feature throughout the different phases of fruit life-like fruit development, maturation and senescence. Ripening process is the beginning of the senescence process and is an irreversible activity involving several biochemical, physiological and organoleptic changes (Joshi et al.2017). These alterations include changes in fruit colour, flavour, texture, sugar content, carbohydrate content, phenolic compounds, organic acids along with pigment formation, starch breakdown and aroma development, flavourings, etc. As a result, I concluded that fruits that are climatic in nature depend directly on ethylene because these fruits ripen with the help of ethylene, while non-climatic fruits will only ripen and mature if they are still attached to the parent plant (Pathak et al., 2018).

\section{Ethephon}

According to Marzouk and Kassem (2011), the fruit can be consumed directly after ethephon therapy, but at the same time, the shelf life of the fruit is decreased. When etherel is applied to fruit, it is decomposed and results in the production of ethylene in fruit and, ultimately, it is ripened (Singh et al., 2018). Sapkota et al., (2020), examined the result of ethephon application to kiwi fruit and found that fruit treated with $700 \mathrm{ppm}$ ethephon had the highest TSS $\left(16.63^{\circ}\right.$ brix) at the end of the ripening period, while a minimum TSS (12 ${ }^{\circ}$ brix) was found in control fruit 30 days after treatment. When the ripening period was at its peak, maximum PLW (17.28 per cent), maximum TSS / TA (25.57), lowest titrable acidity (0.66 per cent) and highest $\mathrm{pH}$ value (4.08) were found in fruit with $700 \mathrm{ppm}$ while control fruits showed minimum TSS / TA (12.1), lowest PLW (11.8 per cent), maximum acid content (1.1 per cent) and lowest $\mathrm{pH}$ (3.5). Minimum shelf life (16.25 days) was found in fruit with 700 ppm followed by 500 ppm (22.13 days) and maximum shelf life (48.25 days) was found in the control treatment. Dong et al., (2020) showed that the early colouring of grapefruit was promoted by the exogenous application of ethephon. Soluble solids increased in ethephon therapy while titrated acidity decreased. Lavanya et al., 2019, observed that dipping of 750-ppm ethephon at $20^{\circ} \mathrm{C}$ for approximately $5 \mathrm{~min}, 80$ per cent of $\mathrm{RH}$ in mango cv. Neelum showed good results with regard to the maturation process. Sabuz et al., (2019) assessed the effect of six different concentrations $(0,250,500,750$, 1000 and $10,000 \mathrm{ppm}$ ) of ethephon on the ripening of banana fruits. After treatment, the fruit was stored at $23 \pm 2{ }^{\circ} \mathrm{C}$ with a RH of $80 \pm$ 5 per cent. Fruits treated with ethephon @500-1000 ppm were observed to be fully ripened on the 4th day of storage while 250 ppm and control were unripe and fruit, while ethephon@10000 ppm resulted in over ripened fruit on the 4th day of storage on the other hand, 6th day fruits treated with 250 ppm ethephon were ripened and fruit with ethephon@500-1000 ppm was over ripened 
while rotten fruit was over ripened. Pendharkar et al., (2011) treated bananas with different concentrations of ethephon @ 500,750 and 1000 ppm and found that 1000 ppm is best suited for early fruit ripening. In an ethephon effect study on passion fruit, it was shown that $600 \mathrm{mg} / \mathrm{kg}$ was the best treatment, while low ethephon concentrations had a much lower effect on passion fruit ( $\mathrm{Li}$ et al., 1919).

\section{Abscisic acid}

ABA play a significant role throughout the life cycle of a plant. This includes the development of seed and its dormancy, the response of the plant to various stresses and ripening of fruit. The concentration of Abscisic acid is very less concentration in unripe fruits, but its concentration starts increasing with the ripening of the fruit. Exogenous ABA application accelerates respiration and production of ethylene, which results in increased ripening of fruits (Zhang et al., 2009). ABA inclines ethylene release in climacteric type fruits that is why it is known as ripening control factor (Zhang et al., 2009, b).Application of ABA leads to the production of those metabolites, which are involved in the process of fruit ripening i.e. ABA increases ripening in fruits (Giribaldi et al., 2010). Setha (2012) suggested that the application of ABA on fruits play a significant role in regulating the rate of fruit ripening.

Wang et al., (2019) suggested that ABA biosynthesis promoted by ethylene through PpERF3's regulation of the expression of ABA biosynthesis genes PpNCED2/3. Liu (2019) observed that ABA appeared to modulate ripening by interfering not only genes related to cell wall and ethylene but also with the help of genes, which are related to auxin. Siebeneichler et al., (2020) suggested that sucrose application in unripened strawberries results in ripening induction, which depends on the ABA and its derivatives. Pharmacological experiments and network correlation analysis with amine, which is an ABA biosynthesis inhibitor, showed that change in levels of $\mathrm{ABA}$ has a straight effect in increasing $\beta$ carotene content and which is then responsible for the phenotype like increased shelf life. Therefore, change in the levels of $\beta$ carotene will not only result in an improved nutritional value, but it also increases shelf life (Diretto et al., 2020). Balate et al., (2020) found that quality of fruits could be improved by increasing the SS, ratio SS/TA of fruits, with the application of Abscisic acid to roots and leaves. It is proposed that SIPYL9 plays an important role in the regulation of flower abscission and ripening in tomato because it is involved in ABA signalling (Kai et al., 2020).

\section{Nitric Oxide (NO)}

It is reported that the level of nitric oxide is more in unripe fruits in comparison to ripe fruit. In research, it is found that level of NO is highest in cherry and tomato fruits when they are atthe unripe stage. Treatment of NO in banana fruits results in delayed ripeningbecause oflessethylene production (Cheng et al., 2009). Sahu et al., (2020) used SNP (sodium nitroprusside) which is a nitric oxide donorin case of guava fruits. In this study, SNP treatment (@ 0.5, 1.0, and 1.5 $\mathrm{mM}$ ) was used along with control treatment and matured green fruits, which were immersed for 5 minutes. After this treatment, fruits were stored at $20 \pm 3^{\circ} \mathrm{C}$. Out of these treatments, the best results were found in SNP@1.0 mM, in this study fruits decay loss $(22.22 \%)$ and minimum weight loss $(16.31 \%)$ was noted on $12^{\text {th }}$ day of storage. Fruits treatment with $1 \mathrm{mM}$ SNP exhibited a delay in ripening, minimum chlorophyll loss (53.23\%) and slow growth of carotenoid pigments. Guava treatment before storage 
with $1 \mathrm{mM}$ SNP resulted in the least loss of TSS and acidity in comparison to fruits under control. Lossin phenols (22.25\%), antioxidant capacity (25.61\%), flavonoids (26.14\%), ascorbic acid (21.30\%) and radical scavenging activity (RCA) $34.21 \%$ was least in fruits treated with $1.0 \mathrm{mM}$ SNP. This study concluded that post-harvest/shelf life of guava might be increased by $1.0 \mathrm{mM}$ SNP treatment. Gheysarbigi et al., (2020) sprayed SNP on pistachio fruits with $0,15,30,45$ and $60 \mu \mathrm{M}$ for 30 seconds and packing of these fruits were in a plastic tray and then wrapped with LDPE (low-density polyethene) and stored in cold storage at $2 \pm 1{ }^{\circ} \mathrm{C}$ and $93 \pm 2 \% \mathrm{RH}$ for 60 days. The results proved that SNP @ 15 and $30 \mu \mathrm{M}$ was most beneficial for the reduction of hull browning and in increasing the postharvest life as compared to the control treatment.

\section{Potassium permanganate $\left(\mathrm{KMnO}_{4}\right)$}

It has been proved in many scientific research experiments that $\mathrm{KMnO}_{4}$ decreases the ripening process of fruits. $\mathrm{KMnO}_{4}$ is a stable purple solid compound and is used to extend the shelf life of fresh produces (Resende et al., 2001). It reduces the level of ethylene in fruits by oxidizing to $\mathrm{CO}_{2}$ and $\mathrm{H}_{2} \mathrm{O}$. Oxidation of ethylene by potassium permanganate results in carbon dioxide and $\mathrm{H}_{2} \mathrm{O}$ formation (Sorbent systems, 2005). It has been proved that with an increase in the quantity of $\mathrm{KMnO}_{4}$, level of ethylene gas is decreased and it was estimated that $20 \mathrm{gm}$ of $\mathrm{KMnO}_{4}$ is able to reduce about $2.2 \%$ of ethylene (Correa et al., 2005). Osman et al., (2008) also advocated that potassium permanganate is a strong oxidizing agent, which readily oxidize ethylene and delays ripening in climacteric fruits such as banana, kiwi fruit, tomato, mango and avocado. Treatment with $\mathrm{KMnO}_{4}$ decreases postharvest losses, which help in delaying in the ripening process of fruits (Ishaq et al., 2009).
Kaur and Kuldip (2011) concluded in peach fruits that $\mathrm{KMnO}_{4}$ treated showed less spoilage and physiological loss in weight during storage in comparison to control. Elzubeir et al., (2018) resulted that waxing of tomato fruits with 1.0 and $2.0 \mathrm{gm}$ potassium permanganate, delayed the ripening by 1,3 and 4 days, respectively, in comparison to the control one. Packing of fruits in carton boxes with 1 and $2 \mathrm{~g}$ potassium permanganate, respectively reduce the weight loss of fruits by $29.1 \%, 38.1 \%$ and $46.0 \%$ (with $0.0,1.0$ and $2.0 \mathrm{~g}$ potassium permanganate, respectively), in comparison to control one. Iqbal et al., (2019) suggested that a KMnO4 treated wrapping material could be utilized for enhancing the shelf life of tomatoes, which retards respiration rate, and delaying in ripening. The effect of ethylene treatments in different concentrations and packaging types on banana fruit was studied to improve storage life and physicochemical quality. As ethylene, absorbent zeolite and $\mathrm{KMnO}_{4}$ were used in storage along with banana at $25-28^{\circ} \mathrm{C}$ of temperature and $85-95 \%$ of $\mathrm{RH}$. Physicochemical analysis (e.g. total soluble solids, weight loss, firmness, peel colour changes and TA) were performed to estimate the effect of treatments during storage. Results showed that $\mathrm{KMnO}_{4}$-zeolite $\left(\mathrm{T}_{4}: 10 \mathrm{~g}\right)$ showed reduction (the higher amount was applied) and retarded the change in colour of peel, firmness $(28.2 \%)$, percent weight loss (9.62\%), TA $(0.084 \%$ malic acid), TSS $(12.1 \%$ Brix) and the banana storability (Yin et al., 2020).

\section{Oxalic acid}

Oxalic acid treatment decreases the deterioration of fruits throughout storage. Increased shelf life and lower decay rate were observed in mango fruits when treated with $5 \mathrm{~mm}$ oxalic acid after harvesting and in controlled atmosphere storage (Zheng et al., 2005). Production of ethylene is very less in 
fruits, which treated with oxalic acid @5mm in comparison to control fruits (Zheng et al., 2007). Wang et al., (2008) also advocated that production of ethylene is reduced in fruits treated with oxalic acid @ 5 mm which delays the senescence in jujube fruit. Wu et al., (2011) treated plum fruits with oxalic acid @ $5 \mathrm{~mm}$ and packed in polyethene bags and stored at $25^{\circ} \mathrm{C}$ for 12 days and found that oxalic acid treated fruits has more shelf life in comparison to control fruits. Treatment of oxalic acid@20mm results in reduced respiration rate and declined production of ethylene in banana fruits in comparison to control (Huang et al., 2013). Ali et al., (2019) submitted that application of oxalic acid before harvesting of fruits might be helped in maintaining the quality of kiwifruit and delay in ripening of fruit, improvement in ascorbic acid content and ethanol fermentation regulation.

Ripening process of plum fruits at the time of their storage was delayed when treated with oxalic acid, in comparison to control (Martínez et al., 2019). Uzumcu et al., (2020) investigated the effect of oxalic acid before the harvesting of fruits on shelf life of apricot cv. 'Roxana'. For this purpose, different dosages $(0,1,2,4$ and $8 \mathrm{mM})$ of oxalic acid solution were applied 7 days before optimal harvest stage. After harvesting fruits at optimal stage (firm-ripe stage), were immediately transported to the postharvest physiology laboratory and kept at room $\left(20 \pm 1^{\circ} \mathrm{C}\right)$ temperature and $50-60 \%$ relative humidity conditions for 8 days for shelf-life evaluation. During the storage period, an analysis was carried out at an interval of 2 days concerning physical and chemical traits like fruit firmness, fruit colour soluble solids content, titratable acidity, and evaluation of loss of weight, ethylene production and respiration rate. As a result, all treatments of oxalic acid performed better in comparison to control fruits in terms of quality parameters.

\section{Salicylic acid}

Babalar et al., (2007) studied the effect of different concentrations of SA on strawberry fruits and found that application of SA @ $2 \mathrm{~mm}$ resulted in a reduction in the production of ethylene and fungal decay. SA @ $2 \mathrm{~mm}$ retains the best quality of strawberry fruits compared to other treatments and control. It was observed that the treatment of SA on sugar apple resulted in reduced respiration rate and inclined the activity of antioxidant enzymes. Mo et al., (2008) concluded that fruits SA treated fruits showed delayed in the ripening of fruits of sugar apple. Loss in weight of fruits is reduced in kiwifruits fruits, which are treated with SA in comparison to control (Fattahi et al., 2010).Bal et al (2019) proved that level of bioactive compounds and high quality of fruit can be maintained by using alginate enriched with salicylic acid than any other coating treatments during storage at $0-1{ }^{\circ} \mathrm{C}$ of 40 days. Lo'ay (2017) also advocated that SA proved to be effective in delaying fruit ripening along with preserving cluster quality of grapes cv. Superior seedless. Lo'ay and Khateeb (2011) also advocate delaying in ripening in guava fruit. Ansarifar et al., (2019) evaluated that the highest fruit firmness in salicylic acid $(11.46 \mathrm{~N})$ treatments. Soluble solids content and improved shelf life were observed in salicylic acid (27.5 days) treated fruits, while it is only 14 days in case of controlled apricot fruits.

\section{Hydrogen Sulphide $\left(\mathrm{H}_{2} \mathrm{~S}\right)$}

Hu et al., (2014) advocated that the shelf life of pear slices could be increased by the application of $\mathrm{H}_{2} \mathrm{~S}$ by inhibiting developments of many fungal pathogens. Treatment with $\mathrm{H}_{2} \mathrm{~S} @ 45$ and $90 \mu \mathrm{mol} \mathrm{L} \mathrm{L}^{-1}$ delayed the maturation and senescence in case of kiwifruit (Zhu et al., 2014). Treatment of $\mathrm{H}_{2} \mathrm{~S}$ with $1 \mathrm{~mm}$ of sodium hydrosulphide results in 
delayed ripening of banana and deferred the senescence (Ge et al., 2017). Hu et al., (2019) showed that by the inhibition of synthesis of endogenous ethylene and regulating ethylene signal transduction exogenous $\mathrm{H}_{2} \mathrm{~S}$ results in delayed fruit softening and the ripening process of tomato fruit at the time of storage. Yao et al., (2020) found that change of colour in tomato fruit was delayed by application of $\mathrm{H}_{2} \mathrm{~S}$ and it maintained higher chlorophyll, lowered flavonoids throughout storage, and increased the post-harvest life of fruits. By regulating cell wall degrading enzyme genes and affecting ethylene signal transduction pathway genes, $\mathrm{H}_{2} \mathrm{~S}$ delays the senescence and ripening of kiwifruit (Lin et al., 2020).

Besides, above said chemicals some other molecules are also used for this purpose. Various scientist have performed research studies in different crops as summarized in following table

\begin{tabular}{|l|l|l|l|l|}
\hline S.No. & Chemical & Crop & Result & Reference \\
\hline $\mathbf{1}$ & Kinetin & Sapota & Delay in ripening & Kaur et al., 2019b \\
\hline $\mathbf{2}$ & 1 MCP & Plum & $\begin{array}{l}\text { Extend shelf life, Reduces weight } \\
\text { loss }\end{array}$ & Xu et al., 2020 \\
\hline $\mathbf{3}$ & Methyl jasmonate & Strawberry & Accelerate ripening Process & Han et al., 2019 \\
\hline $\mathbf{4}$ & $\begin{array}{l}\text { Methyl salicylate and 1 } \\
\text { MCP }\end{array}$ & Tomato & Delay in ripening of fruit & Min et al., 2018 \\
\hline $\mathbf{5}$ & $\begin{array}{l}\text { Sodium benzoate } \\
\text { Sodium } \\
\text { dichloroisocyanurate }\end{array}$ & Pear & Increases shelf life & Kaur et al., 2019 \\
\hline $\mathbf{6}$ & Banana & Delay in ripening and senescence & Wu et al., 2018 \\
\hline
\end{tabular}

\section{Future perspectives}

Fruit development and ripening are prime and significant phases in plant life in field of horticulture. Many research trials are still going on these phases due to short shelf life and perishable nature of the fruit. These are the prime causes for huge and considerable economic losses. From review of literature, it is concluded that ethylene plays a critical role in ripening process, but recently, focus is done on the concept that some other molecules including processes are also responsible for the same. It is need of the hour to develop and field test transgenic plants that are specifically suited to grow well in sustainable agricultural systems that have nominal dependence on chemical involvement and synergistic impact on metabolism of the plant. Short shelf life and perishable nature of the fruit can be managed by finding such chemicals or compounds, which can early or delay the ripening process in fruits. By doing so we can avoid huge economic losses due to market glut of main production season.

\section{Acknowledgements}

The authors are thankful to Dean, Dr Ramesh Sadawarti and Head of Department, Horticulture, Dr Anis Ahmed Mirza for their valuable contribution and encouragement.

\section{References}

Ali, M., Liu, M. M., Wang, Z. E., Li, S. E., Jiang, T. J., and Zheng, X. L. (2019). Pre-harvest spraying of oxalic acid improves postharvest quality associated with increase in ascorbic acid and regulation of ethanol fermentation in kiwifruit cv. Bruno during storage. Journal of Integrative Agriculture, 18(11), 2514-2520.

Anon, (2018), http://apeda.in/agriexchange/ 
India\%20Production/India_Production s.aspx?cat=fruit and hsc ode $=1046$

Ansarifar, E. (2019). Effect of postharvest application of salicylic acid, oxalic acid and nitric oxide on improving qualitative properties and extending the shelf life of fresh apricot fruit cv. 'Sharoudi'. Food Science and Technology, 16(92), 177-189.

Babalar, M., Asghari, M., Talaei, A., and Khosroshahi, A. (2007). Effect of preand postharvest salicylic acid treatment on ethylene production, fungal decay and overall quality of Selva strawberry fruit. Food chemistry, 105(2), 449-453.

Bal, E. (2019). Effects of alginate edible coating enriched with salicylic and oxalic acid on preserving plum fruit (Prunus salicina L. cv. 'Black amber') quality during postharvest storage. Acta Scientiarum Polonorum. Hortorum Cultus, 18(4), 35-46.

Balate, C. A., de Souza, D. C., Silva, L., Resende, L. V., de Freitas, S. T., and Guerra, T. S. (2020). Abscisic acid on the quality of tomato fruits. Embrapa Semiárido-Artigo em periódico indexado, 19, 38-42.

Balota, M., Cristescu, S., Payne, W. A., te Lintel Hekkert, S., Laarhoven, L. J. J., F. J. M. Harren, (2004). Ethylene production of two wheat cultivars exposed to desiccation, heat, and paraquat-induced oxidation. Crop science, 44(3), 812-818.

Boora, R. S. (2012). Improvement in guava (Psidium guajava L.)-A review. Agricultural Reviews, 33(4), 341-349.

Bouzayen, M., Latché, A., Nath, P., Pech, J. (2010). Mechanism of fruit ripening. In Plant developmental biologyBiotechnological perspectives (pp. 319-339). Springer, Berlin, Heidelberg.

Corrêa, S. F., Da Silva, M. G., Oliveira, J. G.,
Aroucha, E. M. M., Silva, R. F., Pereira, M. G., and Vargas, H. (2005). Effect of the potassium permanganate during papaya fruit ripening Ethylene production. In Journal de Physique IV (Proceedings), 125, 869- 871.

Dal, R. I., A. Pilati, Velasco, Moser, Costa and Boschetti (2010). Ethylene production during grape berry development and expression of genes involved in ethylene biosynthesis and response. Acta Hort. (ISHS) 884:7380.

Diretto, G., Frusciante, S., Fabbri, C., Schauer, N., Busta, L., Wang, Z. and Jetter, R. (2020). Manipulation of $\beta$-carotene levels in tomato fruits results in increased ABA content and extended shelf life. Plant biotechnology journal, 18(5), 11851199.

Dong, T., Zheng, T., Fu, W., Guan, L., Jia, H., and Fang, J. (2020). The Effect of Ethylene on the Color Change and Resistance to Botrytis cinerea Infection in 'Kyoho'Grape Fruits. Foods, 9(7), 892.

Elzubeir, M. M., Abu-bakr, A., Osman, O. A., and Safi, A. I. A. (2018). Effect of waxing and potassium permanganate on quality and shelf life of mango fruits. American Journal of Biology and Life Sciences, 6(1), 1-7.

Fattahi, J., Fifall, R. and Babri, M. (2010). Postharvest quality of kiwifruit (Actinidia deliciosa cv. Hayward) affected by pre-storage application of salicylic acid. South Western J. Hortic. Biol. Environ, 1, 175-186.

Ge Y., Hu K. D., Wang S. S., Hu L. Y., Chen X. Y., Li Y. H., (2017). Hydrogen sulphide alleviates postharvest ripening and senescence of banana by antagonizing the effect of ethylene. PLoS One 12: e0180113. 10.1371/journal.pone.0180113 
Gheysarbigi, S., Mirdehghan, S. H., Ghasemnezhad, M., and Nazoori, F. (2020). The inhibitory effect of nitric oxide on enzymatic browning reactions of in-package fresh pistachios (Pistacia vera L.). Postharvest Biology and Technology, 159, 110998.

Giribaldi, M., Gény, L., Delrot, S., and Schubert, A. (2010). Proteomic analysis of the effects of ABA treatments on ripening Vitis vinifera berries. Journal of Experimental Botany, 61(9), 2447-2458.

Han, Y., Chen, C., Yan, Z., Li, J., and Wang, Y. (2019). The methyl jasmonate accelerates the strawberry fruits ripening process. Scientia Horticulturae, 249, 250-256.

Hu, K. D., Wang, Q., Hu, L. Y., Gao, S. P., Wu, J., Li, Y. H., (2014). Hydrogen sulphide prolongs postharvest storage of fresh-cut pears (Pyrus pyrifolia) by alleviation of oxidative damage and inhibition of fungal growth. PloS One 9(1), e85524.

Hu, K. D., Zhang, X. Y., Wang, S. S., Tang, J., Yang, F., Huang, Z. Q., and amp; Yao, G. F. (2019). Hydrogen sulfide inhibits fruit softening by regulating ethylene synthesis and signaling pathway in tomato (Solanum lycopersicum). HortScience, 54(10), 1824-1830.

Huang, H., Jing, G., Guo, L., Zhang, D., Yang, B., Duan, X. and Jiang, Y. (2013). Effect of oxalic acid on ripening attributes of banana fruit during storage. Postharvest Biology and Technology, 84, 22-27.

Iqbal, H. M., Akbar, Q. A., and Yousaf, S. (2019). Study on controlling physiological losses during marketing of tomato (Lycopersicon esculentum MILL.). Int. J. Biol. Biotech. 16 (3): 709-717.
Ishaq, S., Rathore, H. A., Masud, T., and Ali, S. (2009). Influence of postharvest calcium chloride application, ethylene absorbent and modified atmosphere on quality characteristics and shelf life of apricot (Prunus armeniaca L.) fruit during storage. Pak. J. Nutr, 8(6), 861865.

Jiang, Y., Joyce, D. C., and Macnish, A. J. (2000). Effect of abscisic acid on banana fruit ripening in relation to the role of ethylene. Journal of plant growth regulation, 19(1), 106-111.

Joshi, H., Kuna, A., Lakshmi, M. N., Shreedhar, M., and Kumar, A. K. (2017). Effect of stage of maturity, ripening and storage on antioxidant content and activity of Mangifera indica L. var. Manjira. International Journal of Food Science and Nutrition, 2(3), 1-9.

Kai, W., Wang, J., Liang, B., Fu, Y., Zheng, Y., Zhang, W., and amp; Leng, P. (2019). PYL9 is involved in the regulation of ABA signaling during tomato fruit ripening. Journal of experimental botany, 70(21), 63056319.

Kaur, A. P., and Kuldip, S. (2011). Effect of ethylene absorbent on post-harvest physiology of peach at ambient storage. International Journal of Agricultural Sciences, 7(2), 378- 381.

Kaur, A., Gill, P. P. S., and Jawandha, S. K. (2019). Effect of sodium benzoate application on quality and enzymatic changes of pear fruits during low temperature. Journal of food science and technology, 56(7), 3391-3398.

Kaur, M., and Kaur, A. (2019b) Effect of post-harvest chemicals on storability of sapota cv. Kalipatti. International Journal of Agricultural Science and Research, 9(6), 83-92.

Lavanya, E. K., Rao, D. B., Edukondalu, L., Lakshmypathy, R., and Rao, V. S. 
(2019). Effect of ethephon and storage temperature on physico-chemical changes during ripening of Mango (Mangifera indica L.) Cv. Neelum. Current Journal of Applied Science and Technology, 1-11.

Li, J., Liao, J., Lu, Y., Wei, F., Chen, Y., LU, X., and Dong, X. (2019). Effect of Ethephon and Ethanol Treatments on Ripening Quality of Passion Fruit (Passiflora edulis Sim.). Journal of Shanxi Agricultural Sciences, (9), 3.

Li, X., Xu, C., Korban, S. S., Chen, K. (2010). Regulatory mechanisms of textural changes in ripening fruits. Critical Reviews in Plant Sciences, 29(4), 222-243.

Lin, X., Yang, R., Dou, Y., Zhang, W., Du, H., Zhu, L., and Chen, J. (2020). Transcriptome analysis reveals delaying of the ripening and cell-wall degradation of kiwifruit by hydrogen sulfide. Journal of the Science of Food and Agriculture, 100(5), 2280-2287.

Liu, N. (2019). Effects of IAA and ABA on the immature peach fruit development process. Horticultural plant journal, 5(4), 145-154.

Lo'ay, A. A. (2017). Preharvest salicylic acid and delay ripening of 'superior seedless' grapes. Egyptian journal of basic and applied sciences, 4(3), 227230.

Lo'ay, A. A., and A. Y. El Khateeb. "Delaying guava ripening by exogenous salicylic acid." Journal of Plant Production 2.5 (2011): 715-724.

Martínez-Esplá, A., Serrano, M., Martínez-Romero, D., Valero, D., and Zapata, P. J. (2019). Oxalic acid preharvest treatment increases antioxidant systems and improves plum quality at harvest and during postharvest storage. Journal of the Science of Food and Agriculture, 99(1), 235-243.
Marzouk, H. A., and Kassem, H. A. (2011). Improving yield, quality, and shelf life of Thompson seedless grapevine by preharvest foliar applications. Scientia Horticulturae, 130(2), 425-430.

Min, D., Li, F., Zhang, X., Shu, P., Cui, X., Dong, L. and Li, J. (2018). Effect of methyl salicylate in combination with 1-methylcyclopropene on postharvest quality and decay caused by Botrytis cinerea in tomato fruit. Journal of the Science of Food and Agriculture, 98(10), 3815-3822.

Mitra, S. K., Gurung, M. R., and amp; Pathak, P. K. (2007). Guava production and improvement in India: An overview. In International Workshop on Tropical and Subtropical Fruits 787 (pp. 59-66).

Mo, Y., Gong, D., Liang, G., Han, R., Xie, J., and Li, W. (2008). Enhanced preservation effects of sugar apple fruits by salicylic acid treatment during post-harvest storage. Journal of the Science of Food and Agriculture, 88(15), 2693-2699.

Osman, H. E and A.A. Abu-Goukh (2008). Effect of polyethylene film lining and gibberellic acid on quality and shelflife of banana fruits. Journal of Agricultural Science, 16 (2), 242-261.

Pathak, S., Sriramulu, S., Thandavan, S. P., Jothimani, G., Banerjee, A., and Marotta, F. (2018). Enhancement of shelf life of the climacteric fruits: a review on application of crispri technology. Trends in Technical and Scientific Research, 1(2), 555557.

Pendharkar, P. Y., Hiwale, S. S., and Patil, A. B. (2011). Studies on the effect of ethrel on ripening of banana fruits cv. Grand Naine. Asian Journal of Horticulture, 6(2), 309- 312.

Resende, J. M., Vilas Boas, E. D. B., and Chitarra, M. I. F. (2001). Uso de atmosfera modificada na conservação pós-colheita do maracujá amarelo. 
Ciência Agrotécnica, 25(1), 159-168.

Reza, S. E., and Uddin, M. N. (2020). Study of the Effect of Ethephon Treatment on Proximate Composition of Banana (Musa Sepientum). IOSR Journal of Environmental Science, Toxicology and Food Technology. 14(3), 36-44.

Sabuz, A. A., Chowdhury, M. G. F., Molla, M. M., Khan, M. H. H., and Miaruddin, M. (2019). Effect of Ethephon on ripening and postharvest quality of mango. Bangladesh Journal of Agricultural Research, 44(3), 453467.

Sahu, S. K., Barman, K., and Singh, A. K. (2020). Nitric oxide application for postharvest quality retention of guava fruits. Acta Physiologiae Plantarum, 42(10), 1-11.

Sapkota, M., Pandey, D., Shrestha, B., and Sapkota, S. (2020). Effect of ethephon on post- harvest characteristics of kiwi (Actinidia deliciosa cv. Monty) in Dolakha, Nepal. Journal of Bioscience and Agriculture Research, 23(01), 1885-1893.

Setha, S. (2012). Roles of abscisic acid in fruit ripening. Walailak Journal of Science and Technology (WJST), 9(4), 297-308.

Sharma, D. R., and Krishna, H. (2014). Fruit Production: Major Fruits. Daya publishing House.

Siebeneichler, T. J., Crizel, R. L., Camozatto, G. H., Paim, B. T., da Silva Messias, R., Rombaldi, C. V., and Galli, V. (2020). The postharvest ripening of strawberry fruits induced by abscisic acid and sucrose differs from their in vivo ripening. Food chemistry, 317, 126407.

Singh, J., Bal, J. S., Singh, Sukhdip and Mirza, A. (2018). Assessment of chemicals and growth regulators on fruit ripening and quality: A review. Plant Archives 18(2), 1215-1222
Sorbentsystems.com (2005). The problem: ethylene gas. Disponível em:\&lt;http://www.sorbentsystems.co m/epaxtech.html\&gt;. Acesso em Srivastava, A., and Handa, A. K. 2005. Hormonal regulation of tomato fruit development: a molecular perspective. Journal of plant growth regulation, 24(2), 67-82.

Srivastava, M. K., and Dwivedi, U. N. (2000). Delayed ripening of banana fruit by salicylic acid. Plant Science, 158(1-2), 87-96.

Tripathi, K., Pandey, S., Malik, M., and Kaul, T. (2016). Fruit ripening of climacteric and nonclimacteric fruit. Journal of Environmental and Applied Bioresearch, 4(1), 27-34.

Üzümcü, S. S., Koyuncu, M. A., OnursaL, C. E., Güneyli, A., and Erbaş, D (2020). Effect of Pre-Harvest Oxalic Acid Treatment on shelf-life of Apricot cv.'Roxana'. Nevşehir Bilim ve Teknoloji Dergisi, 9(1), 73-80.

Wang, Q., Lai, T., Qin, G., and Tian, S. (2008). Response of jujube fruits to exogenous oxalic acid treatment based on proteomic analysis. Plant and cell physiology, 50(2), 230- 242.

Wang, X., Zeng, W., Ding, Y., Wang, Y., Niu, L., Yao, J. L. and Wang, Z. (2019). PpERF3 positively regulates ABA biosynthesis by activating PpNCED2/3 transcription during fruit ripening in peach. Horticulture research, 6(1), 1-10.

Wu, F., Zhang, D., Zhang, H., Jiang, G., Su, X., Qu, H. and Duan, X. (2011). Physiological and biochemical response of harvested plum fruit to oxalic acid during ripening or shelflife. Food Research International, 44(5), 1299-1305.

Wu, Q., Li, T., Chen, X., Wen, L., Yun, Z., and Jiang, Y. (2018). Sodium dichloroisocyanurate delays ripening 
and senescence of banana fruit during storage. Chemistry Central Journal, 12(1), 1-11.

Xu, Y., Huan, C., Jiang, T., Zheng, X., and Brecht, J. K. (2020). Effects of 1methylcyclopropene treatment on quality and anthocyanin biosynthesis in plum (Prunus salicina cv. Taoxingli) fruit during storage at a non-chilling temperature. Postharvest Biology and Technology, 169, 111291.

Yao, G. F., Li, C., Sun, K. K., Tang, J., Huang, Z. Q., Yang, F. and Zhang, H. (2020). Hydrogen Sulfide Maintained the Good Appearance and Nutrition in Post-harvest Tomato Fruits by Antagonizing the Effect of Ethylene. Frontiers in Plant Science, 11, 584.

Yin, C. Y., Akhir, M. A. M., and Uda, M. N. A. (2020). Effect of Potassium Permanganate and Zeolite on Shelf Life and Quality of Musa Acuminata. In IOP Conference Series: Materials Science and Engineering 864(1), 012141

Zhang, M., Leng, P., Zhang, G., and Li, X. (2009b). Cloning and functional analysis of 9-cis- epoxycarotenoid dioxygenase (NCED) genes encoding a key enzyme during abscisic acid biosynthesis from peach and grapefruits. Journal of plant physiology, 166(12), 1241- 1252.

Zhang, M., Yuan, B., and Leng, P. (2009). The role of $\mathrm{ABA}$ in triggering ethylene biosynthesis and ripening of tomato fruit. Journal of Experimental Botany, 60(6), 1579- 1588

Zheng, X. L., Tian, S. P., Xu, Y., and Li, B. Q. (2005). Effects of exogenous oxalic acid on ripening and decay incidence in mango fruit during storage at controlled atmosphere. Journal of Fruit Science, 22(4), 351-355.

Zheng, X., Tian, S., Gidley, M. J., Yue, H., and Li, B. (2007). Effects of exogenous oxalic acid on ripening and decay incidence in mango fruit during storage at room temperature. Postharvest biology and technology, 45(2), 281-284.

Zhu, L., Wang, W., Shi, J., Zhang, W., Shen, Y., Du, H., and Wu, S. (2014). Hydrogen sulphide extends the postharvest life and enhances antioxidant activity of kiwifruit during storage. Journal of the Science of Food and Agriculture, 94(13), 2699-2704.

\section{How to cite this article:}

Pawandeep Singh, Ankush Tarkha, Prassan Kumar and Jatinder Singh. 2020. Impact of Chemicals on the Ripening Physiology of Fruits. Int.J.Curr.Microbiol.App.Sci. 9(12): 219-229. doi: https://doi.org/10.20546/ijcmas.2020.912.029 